A Platinum Open Access Journal

for Organic Chemistry
Review

Arkivoc 2021, part ix, 200-217

\title{
Synthesis and anti-influenza activity of five member heterocycles containing compounds: a mini review
}

\author{
Samar S. Tawfik, ${ }^{a}$ Sadaf Zarechian, ${ }^{b}$ and Abdelbasset A. Farahat ${ }^{* a, b}$ \\ a Department of Pharmaceutical Organic Chemistry, Faculty of Pharmacy, Mansoura University, Mansoura \\ 35516, Egypt \\ ${ }^{b}$ Master of Pharmaceutical Sciences Program, California Northstate University, 9700 W Taron Dr., Elk Grove, \\ CA 95757, U.S.A. \\ Email: abdelbasset.farahat@cnsu.edu
}

Received 07-23-2021

Accepted 10-09-2021

Published on line 11-08-2021

\section{Abstract}

This survey covers the literature data published on the chemistry of synthesis of five membered heterocycles containing compounds that show anti-influenza activity. Furthermore, we made a brief review of the antiinfluenza activity of these compounds. We believe that this review will be a useful resource for researchers working on developing of anti-influenza agents.
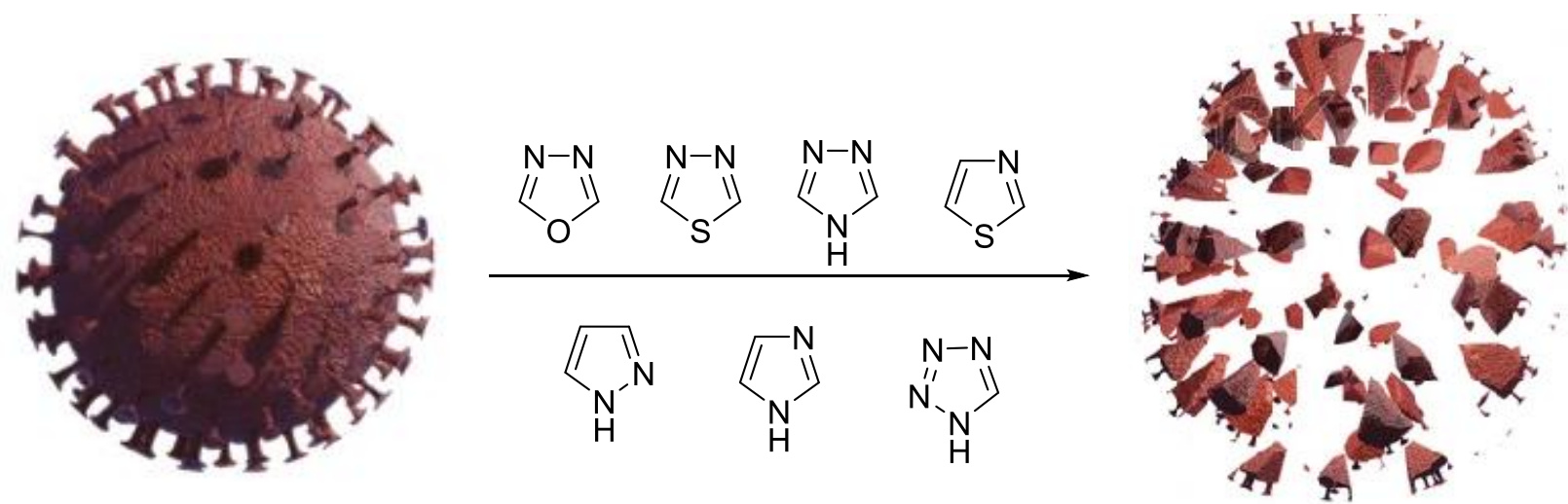

\section{Influenza Virus}

Keywords: Anti-influenza, five members heterocycles, biological activity, thiazoles, oxazoles 


\section{Table of Contents}

1. Introduction

2. Thiazoles

3. Oxadiazoles

4. Triazoles

5. Thiadiazoles

6. Pyrazoles

7. Imidazoles

8. Tetrazoles

References

\section{Introduction}

Influenza is a viral infection caused by various strains of the influenza virus, characterized by a highly contagious, acute respiratory syndrome. It usually presents in a mild form which clears after 3-6 days, but it can also lead to other secondary infections or present in more severe forms, such as pneumonia or acute respiratory distress syndrome, which can be fatal if not treated, particularly in elderly patients. ${ }^{1-4}$

Seasonal influenza is characterized by a sudden onset of fever, cough, headache, muscle and joint pain, severe malaise, sore throat, and a runny nose. Most people recover from fever and other symptoms within a week without requiring medical attention. But influenza can cause severe illness or death especially in people at high risk. Hospitalization and death occur mainly among high-risk groups such as children, elderly patients, patients with chronic respiratory diseases, and pregnant women. Worldwide, these epidemics are estimated to affect $5 \%-10 \%$ of the world's population every year, producing about 3 to 5 million cases of severe illness, and about 290000 to 650000 respiratory deaths. ${ }^{5}$

Preventing both the disease and complications can be achieved by vaccination. If treatment with antivirals is administered without delay, the risk of severe complications can be reduced; however, many virus strains develop high resistance and current drugs lose efficacy, so recently, there has been great interest in developing new remedies for combating influenza. 5,6

Five-membered heterocyclic compounds have shown a wide range of biological activities, ${ }^{7}$ namely thiadiazoles, thiazoles, 1,3,4-oxadiazoles, triazoles, ${ }^{8-21}$ in addition to the benzimidazole ring. ${ }^{22}$ They have been used as scaffolds for the synthesis of a wide range of agents with versatile activities including antibacterial, ${ }^{23,24}$ antifungal, ${ }^{25,26}$ analgesic, anti-inflammatory, ${ }^{17}$ anticancer ${ }^{27,28}$ and antihypertensive activity. ${ }^{29}$

These five-membered heterocyclic rings have also proved to have very effective antiviral activity against a wide range of viruses, making them of great value in antiviral research. ${ }^{30-36}$

Many anti-influenza drugs contain five-membered heterocyclic rings in their structure (Figure 1). Nucleozin contains oxazole ring. ${ }^{37}$ A loading dose and short-term administration of oral ribavirin significantly improved symptoms and signs of influenza type A or B infection, ${ }^{38}$ ribavirin contains triazole ring in its structure. Viramidine, the 3-carboxamidine derivative of ribavirin, is effective against a spectrum of influenza $A$ and $B$ and it also contains triazole moiety in its structure. ${ }^{39}$ Verdinexor, a triazole containing drug is a selective inhibitor of nuclear export, reduces influenza A virus replication in vitro and in vivo. ${ }^{40}$ Originally developed and commercialized as an antiprotozoal agent, Nitazoxanide was later identified as a first-in-class broad-spectrum antiviral drug and has been repurposed for the treatment of influenza. ${ }^{41}$ 
<smiles>Cc1onc(-c2ccccc2)c1C(=O)N1CCN(c2ccc([N+](=O)[O-])cc2Cl)CC1</smiles>

Nucleozin<smiles>O=C(/C=C\n1cnc(-c2cc(C(F)(F)F)cc(C(F)(F)F)c2)n1)NNc1ccccn1</smiles>

Verdinexor<smiles>NC(=O)c1ncn([C@@H]2O[C@H](CO)[C@@H](O)[C@H]2O)n1</smiles>

Ribavirin<smiles>CC(=O)Oc1ccccc1C(=O)Nc1ncc([N+](=O)[O-])s1</smiles>

Nitazoxanide

Figure 1. Anti-influenza drugs containing five-member heterocyclic rings.

This review article describes the synthesis and pharmacological activity of new medications under study that contain five-membered heterocyclic rings and show potential benefits in the treatment of influenza.

\section{Thiazoles}

In 2020, Zhao et al. reported a series of novel thiazoles derived from an FDA-approved drug, nitazoxanide, (Scheme 1) with antiviral activity against influenza and a broad range of viruses. The preferred candidates compounds 1 and $\mathbf{2}$ showed significantly enhanced anti-influenza virus potentials, with 10-fold improvement compared to results with nitazoxanide, and were effective against a variety of influenza virus subtypes including oseltamivir-resistant strains. Notably, the combination using compounds 1, 2 and oseltamivir carboxylate or zanamivir displayed synergistic antiviral effects against oseltamivir-resistant strains. Compound 1 was made by coupling of ethyl chloroformate and tizoxanide in $\mathrm{N}, \mathrm{N}$-dimethyl acetamide and $\mathrm{CH}_{3} \mathrm{CN}, \mathrm{while}$ compound 2 was formed as coupling product of 1-butanesulfonyl chloride and tizoxanide in tetrahydrofuran as shown in Scheme $1 .{ }^{42}$ 
<smiles>CC(=O)Oc1ccccc1C(=O)Nc1ncc([N+](=O)[O-])s1</smiles>

Nitazoxanide<smiles>O=C(Nc1ncc([N+](=O)[O-])s1)c1ccccc1O</smiles>

Tizoxanide<smiles>O=C(Nc1ncc([N+](=O)[O-])s1)c1ccccc1O</smiles>

Tizoxanide

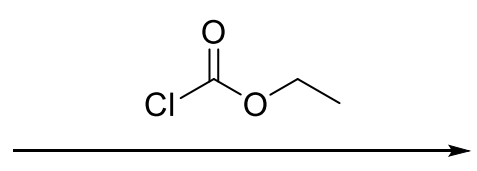

DMF, Pyridine, $\mathrm{CH}_{3} \mathrm{CN}$, r.t.<smiles>CCOC(=O)Oc1ccccc1C(=O)Nc1ncc([N+](=O)[O-])s1</smiles>

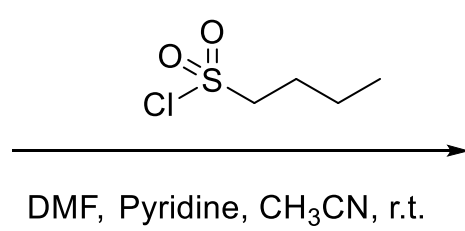<smiles>CCCCS(=O)(=O)Oc1ccccc1C(=O)Nc1ncc([N+](=O)[O-])s1</smiles>

2

\section{Scheme 1}

In 2019, Yarovaya et al. synthesized a series of novel camphecene analogues including the introduction of heterocyclic moieties in place of the terminal hydroxyl group of camphecene. All compounds were tested for cytotoxicity and antiviral activity against influenza virus A/Puerto Rico/8/34 (H1N1) in MDCK cells. Among the tested compounds, compounds 4, 5 demonstrated high antiviral activity, with compound $\mathbf{4}$ showing much less cytotoxicity than other synthesized compounds. Scheme $\mathbf{2}$ shows the synthesis of the target compounds, where camphecene was treated with phosphorous bromide $\left(\mathrm{PBr}_{3}\right)$ in diethyl ether to produce the bromo intermediate $\mathbf{3}$ that was used directly in further reactions. Key compounds 4, $\mathbf{5}$ were prepared by nucleophilic substitution of secondary thiols with the bromo compound $\mathbf{3}$ in the presence of potassium carbonate and 1,8diazabicyclo[5,4,0] undec-7-ene (DBU) in acetonitrile as a solvent. ${ }^{43}$

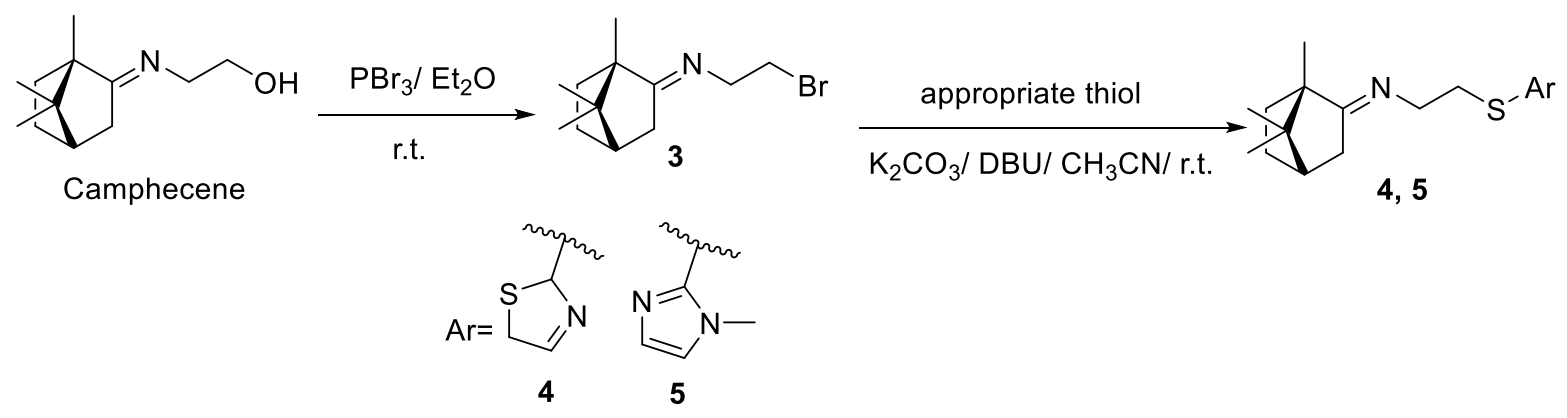

Scheme 2 
Wang reported the synthesis of a series of novel 4,2-bisheterocycle tandem simplified derivatives of the cytotoxic heptapeptide compound Leucamide A, consisting of a methyloxazole and thiazole subunits. Many of these simplified compounds were found to effectively inhibit the human influenza A virus. Several analogues exhibited moderate biological activity and could serve as leads for further optimizations for antiviral research. Compounds A or B were treated with acyl chloride to afford the target compounds $\mathbf{6}$ and $\mathbf{7}$ as scheme $\mathbf{3}$ shows. ${ }^{44}$

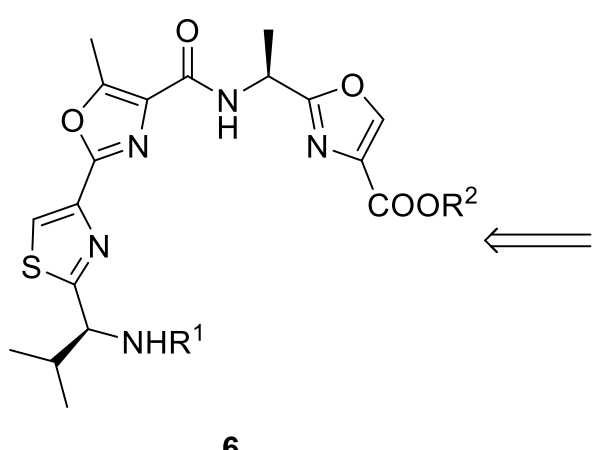

6
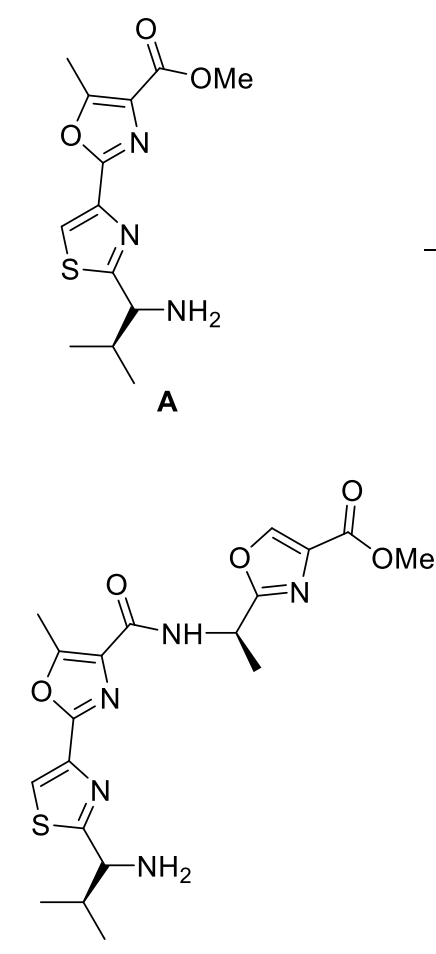

B

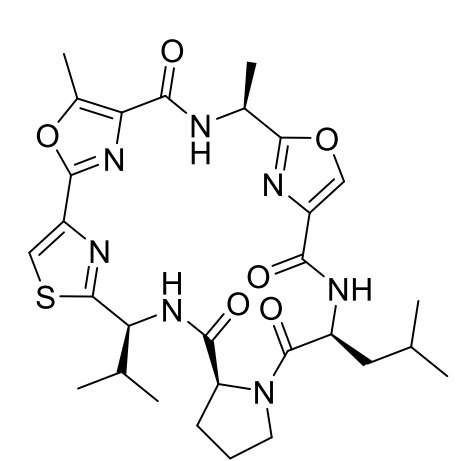

Leucamide A

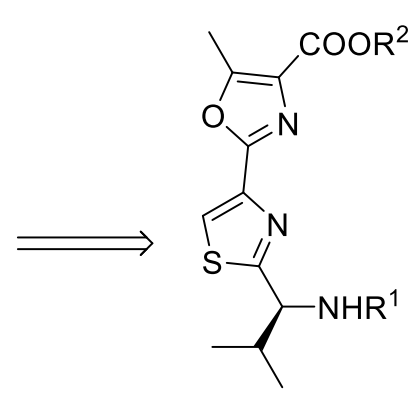

7
$\mathrm{R}^{1} \mathrm{COCl}, \mathrm{NaHCO}_{3}$ AcOEt/ $\mathrm{H}_{2} \mathrm{O}$

r.t./ $24 \mathrm{~h}$

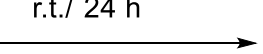

$\mathrm{R}^{1} \mathrm{COCl}, \mathrm{NaHCO}_{3}$ AcOEt/ $\mathrm{H}_{2} \mathrm{O}$ r.t./ $24 \mathrm{~h}$<smiles>[R]NC(c1nc(-c2nc(C(=O)O[R])c(C)o2)cs1)C(C)C</smiles>

6<smiles>[R1]N[C@H](c1nc(-c2nc(C(=O)N[C@@H](C)c3nc(C(=O)O[R2])co3)c(C)o2)cs1)C(C)C</smiles><smiles>[R][CH-][R7]</smiles><smiles>CC(=O)C(C)(C)C</smiles><smiles>CC(=O)C1CCCCC1</smiles>

Scheme 3 


\section{Oxadiazoles}

Oxadiazole-linked heterocycles showed moderate to strong anti-influenza activity as follows.

Hala et al. in 2020 reported the synthesis of new oxadiazole derivatives for exploring their activity against avian influenza. The reaction of the acid hydrazide 9 with carbon disulfide in presence of potassium hydroxide in ethanol afforded the oxadiazole derivative $\mathbf{1 0}$ which showed moderate antiviral activity against avian influenza virus H5N1. ${ }^{45}$

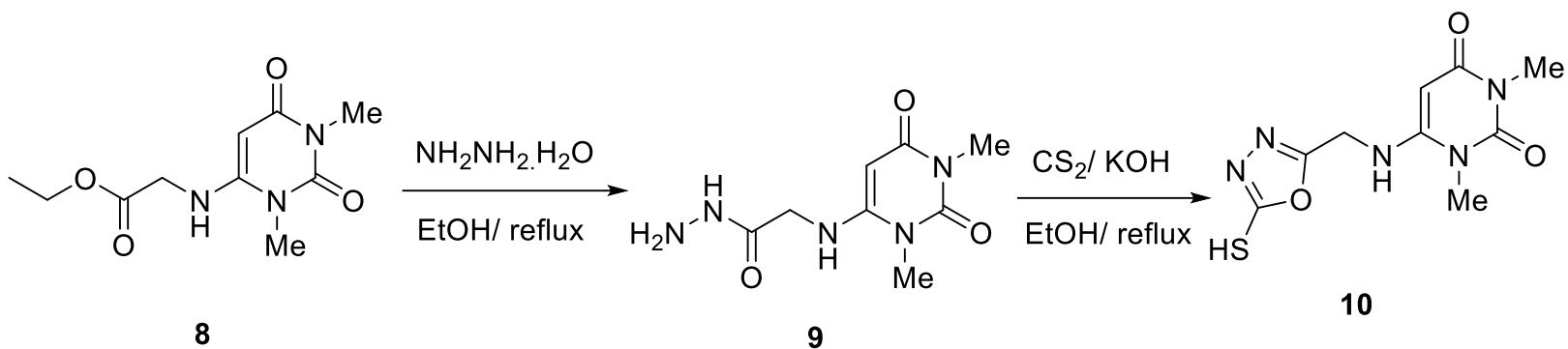

\section{Scheme 4}

In 2018, Silverstova et al. synthesized two series of new adamantyl derivatives of oxadiazole and triazole; 2-(adamantan-1-y/)-5-aryl-1,3,4-oxadiazoles and 2-(adamantan-1-y/)-5-aryl-2H-tetrazoles. In vitro biological studies have shown high inhibitory activity of some of the synthesized compounds against H1N1 influenza A viruses. A mixture of the corresponding aldehyde and the hydrazide 11, was refluxed to produce the intermediate hydrazone 12. Iodine and potassium carbonate were added to the hydrazone $\mathbf{1 2}$ and the reaction mixture was refluxed to produce the final oxadiazole-linked adamantane $13 a-c .{ }^{46}$

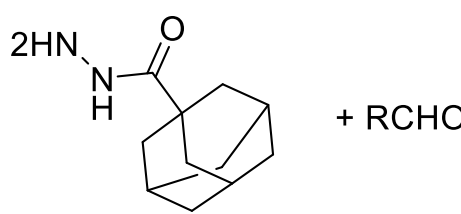

11

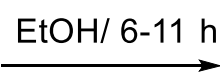

$$
\begin{aligned}
& \text { 13a } R=\text { phenyl } \\
& 13 b R=\text { naphthalen-1-yl } \\
& 13 c R=\text { anthracen }-9-y l
\end{aligned}
$$

12

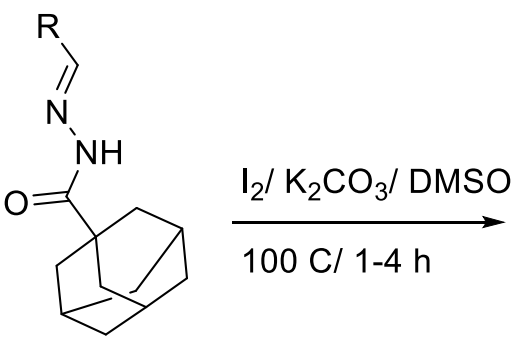

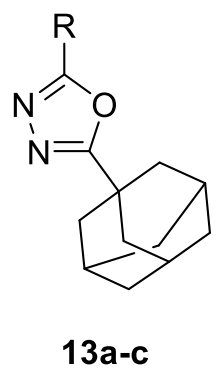

13a-c

\section{Scheme 5}

We have reported a novel series of oxadiazole-based scaffolds that were evaluated in vitro against the highly pathogenic influenza H5N1. Four compounds $\mathbf{1 6 b , c}, \mathbf{2 3 b}$,e showed excellent anti-influenza activity with the oxadiazole derivative having $p$-tolyl at position 5 of the oxadiazole 16c being the most active showing $100 \%$ inhibition at $100 \mu \mathrm{g} / \mu \mathrm{l}$ with an IC50=39 $\mathrm{gg} / \mu \mathrm{l}$. The oxadiazole derivatives $16 \mathrm{a}-\mathrm{c}$ were synthesized through cyclization of the acid $\mathbf{1 4}$ to the final oxadiazole after heating with different acid hydrazides in phosphorus oxychloride as in scheme $6 .{ }^{47}$ 
Scheme 7 shows the synthesis of the oxadiazoles 23a-f starting with the ester $\mathbf{1 7}$ that was produced by esterification of 4-chlorobenzoic acid, then reaction with hydrazine hydrate to furnish the acid hydrazide 18. The produced acid hydrazide was cyclized by refluxing with $\mathrm{CS}_{2} / \mathrm{KOH}$ in ethanol to afford the 2-thiooxadiazole derivative 19 which underwent nitration using a mixture of concentrated $\mathrm{HNO}_{3}$ and concentrated $\mathrm{H}_{2} \mathrm{SO}_{4}$ furnishing the nitro compound $\mathbf{2 0}$ in good yield (68\%). Alkylation of the produced nitro compound 20 with various alkyl halides in DMF and in presence of $\mathrm{K}_{2} \mathrm{CO}_{3}$ at room temperature produced compounds 21a-c. These compounds were further aminated using benzyl or phenethylamine to obtain compounds 23a-f.<smiles>O=C(O)c1ccc(Cl)c([N+](=O)[O-])c1</smiles>

14
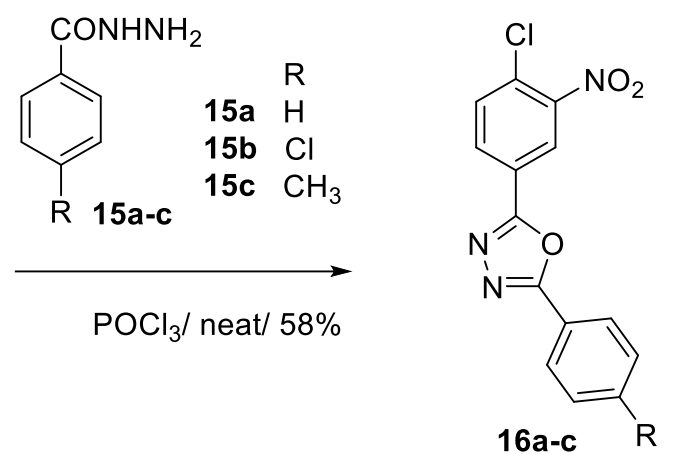

16a ${ }^{R}$

16b Cl

16c $\mathrm{CH}_{3}$

\section{Scheme 6}
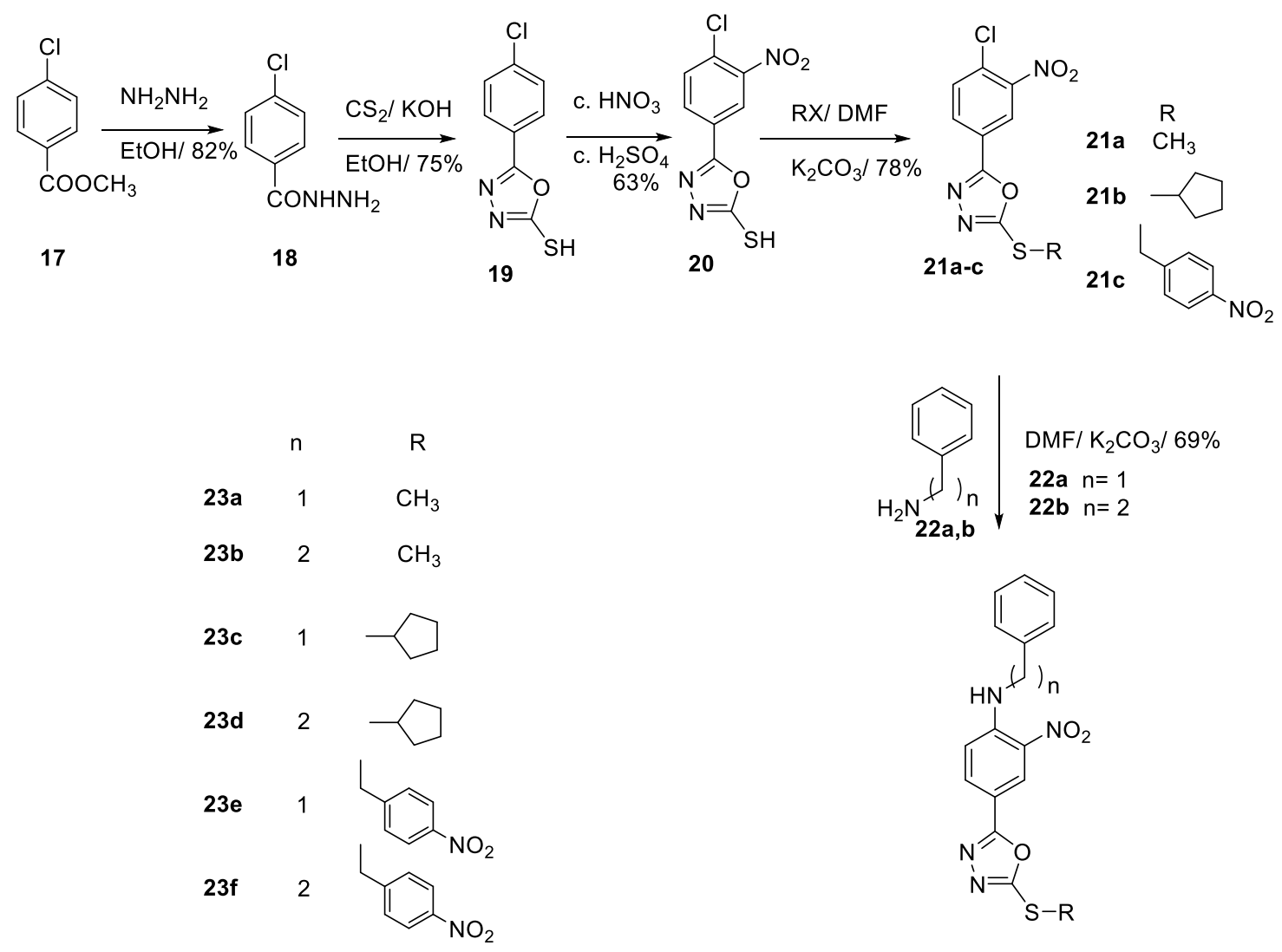

23a-f

\section{Scheme 7}




\section{Triazoles}

In 2013, Flefal et al. used 3-[2-(4-bromphenyl)hydrazono]-5-phenyl-furan-2(3H)-one for preparation of some novel pyrazole, pyridazinone, oxadiazole, triazole, thiazolidine, and thioxopyrimidine derivatives. Ring closure of thiosemicarbazides $\mathbf{2 4 a , b}$ using sodium hydroxide solution led to the formation of the corresponding triazolthiones $\mathbf{2 5 a , b}$. These two compounds were tested for anti-avian influenza virus activity and revealed remarkable antiviral activity against the $\mathrm{H} 5 \mathrm{~N} 1$ virus. $^{48}$<smiles>O=C(NNC(=S)N[Al])c1cc(-c2ccccc2)n([Al])n1</smiles>

24a,b

$\mathrm{Ar}$

a:<smiles>Cc1ccc(Br)cc1</smiles>

b:<smiles>Cc1ccc(Br)cc1</smiles>

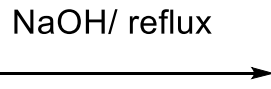

$\mathrm{Ar}^{\prime}$<smiles>Cc1ccccc1</smiles><smiles>COc1ccc(C)cc1</smiles><smiles>[Al]n1nc(-c2n[nH]c(=S)n2[Al])cc1-c1ccccc1</smiles>

$25 a, b$

\section{Scheme 8}

It is well known that the development of entry inhibitors is a promising approach to the inhibition of the influenza virus. In 2019, Yangging et al. used oleanolic acid (OA) which was discovered as a mild influenza hemagglutinin (HA) inhibitor. Herein, as a further study, they reported the preparation of a series of OAsaccharide conjugates via the CuAAC reaction, and the anti-influenza activity of these compounds was evaluated in vitro. Among them, compound 30, an OA-glucose conjugate, showed a significantly increased anti-influenza activity with an IC50 of $5.47 \mu \mathrm{M}$, and no obvious cytotoxic effect on MDCK cells was observed at $100 \mathrm{mM}$. Hemagglutination inhibition assay and docking experiment indicated that compound $30 \mathrm{might}$ interfere with influenza virus infection by acting on HA protein. Broad-spectrum anti-influenza experiments showed $\mathbf{3 0}$ to be robustly potent against five different strains, including influenza A and B viruses, with IC50 values at the low micromolar level. Overall, this finding further extends the utility of OA-saccharide conjugates in anti-influenza virus drug design. ${ }^{49}$ 


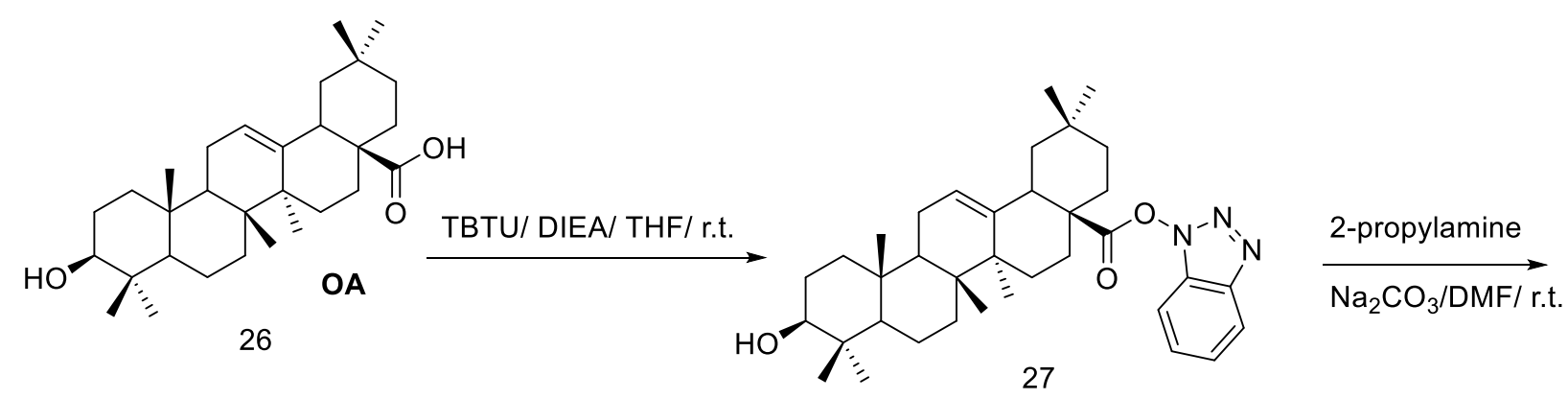<smiles>C#CCNC(=O)C12CCC(C)(C)CC1C1=CCC3C(C)(C)[C@H](O)CC[C@]3(C)[C@@]1(C)CC[C@H]2C</smiles>

28

OA-propalgylamine
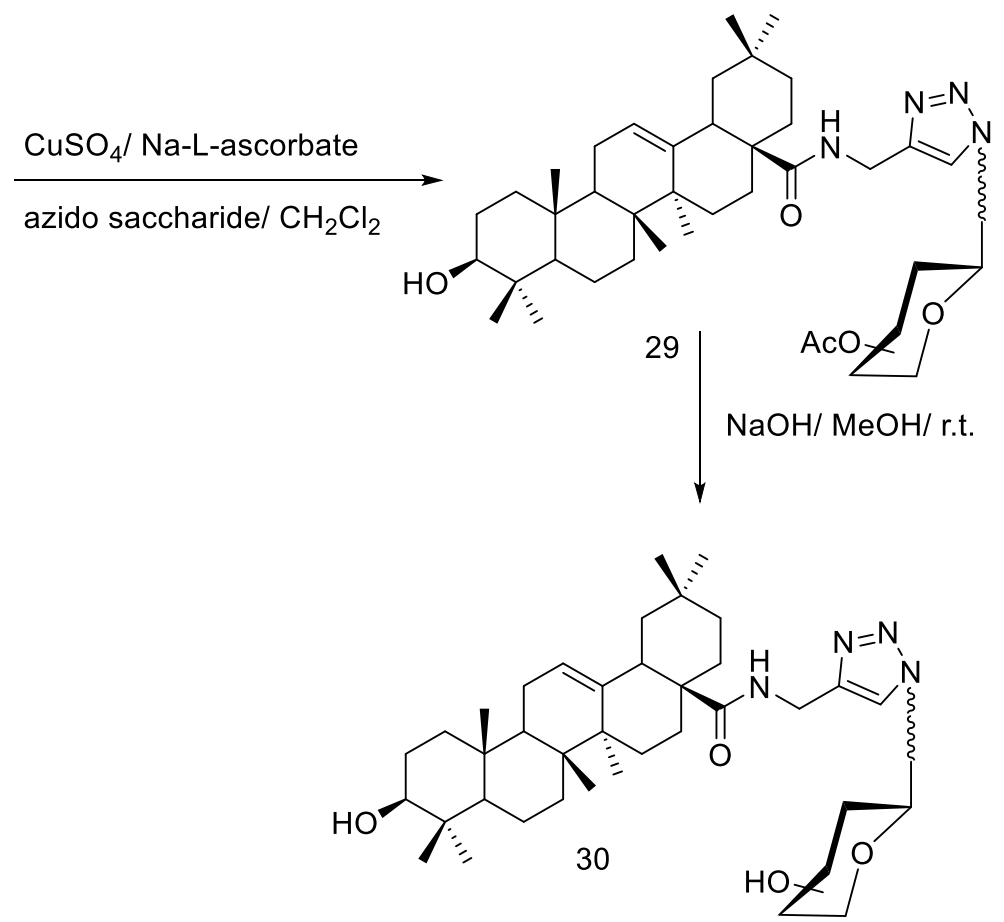

\section{Scheme 9}

The influenza virus nucleoprotein (NP) is a perfect target for anti-influenza drug research Nucleozin and its related derivatives were found to act as NP inhibitors showing anti-influenza activity. Utilizing Nucleozin as a lead molecule, Huimin et al. in 2012 successfully designed and synthesized a series of 1H-1,2,3-triazole-4carboxamide derivatives as new anti-influenza A virus agents. The most potent compound 35 inhibited the replication of various $\mathrm{H} 3 \mathrm{~N} 2$ and $\mathrm{H} 1 \mathrm{~N} 1$ influenza A virus strains. Further computational studies and mechanism investigation approved that compound $\mathbf{3 5}$ can directly target nucleoprotein of influenza $A$ virus to inhibit its nuclear accumulation. The synthetic pathway of compound $\mathbf{3 5}$ is illustrated in scheme $\mathbf{1 0 .} .^{50}$

In our search for effective anti-influenza agents, we synthesized a series of triazole-linked heterocycles, the newly synthesized compounds were tested for their activity against the highly pathogenic avian influenza virus H5N1. The new compounds showed moderate to excellent antiviral activity. 


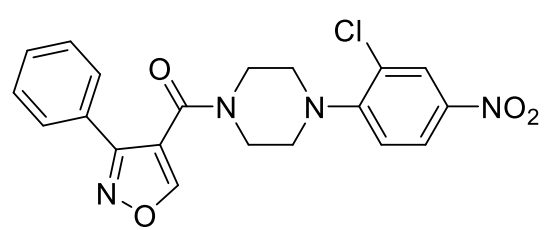

Nucleozin<smiles>COc1ccccc1-n1nncc1C(=O)N1CCN(c2ccc([N+](=O)[O-])cc2Cl)CC1</smiles>

35<smiles>CCOC(=O)c1nnn(-c2ccccc2OC)c1C</smiles>

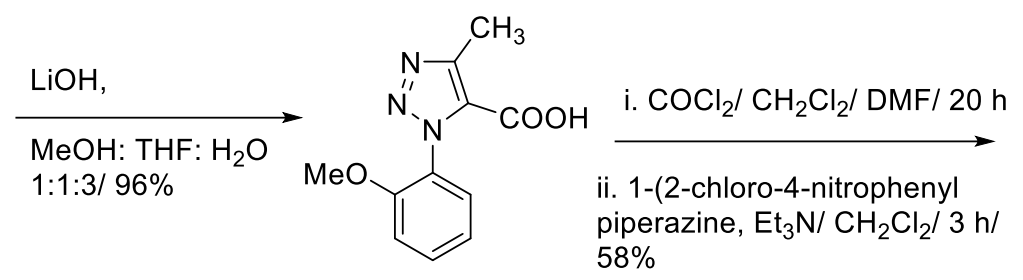<smiles>COc1ccccc1-n1nncc1C(=O)N1CCN(c2ccc([N+](=O)[O-])cc2Cl)CC1</smiles>

\section{Scheme 10}

Scheme $\mathbf{1 1}$ describes the synthesis of the triazole derivatives $\mathbf{3 9 a , b}$ and $\mathbf{4 0}$. Compound $\mathbf{3 6}$ was cyclized to the thiotriazole derivative 37 after refluxing with $5 \% \mathrm{KOH}$ solution. The intermediate thiol was further alkylated either with 2-chloromethyl benzimidazole derivatives $\mathbf{3 8} \mathbf{a}, \mathbf{b}$ to afford the benzimidazole derivatives 39a,b or with ethyl chloroacetate furnishing the thioester triazole derivative 40.47

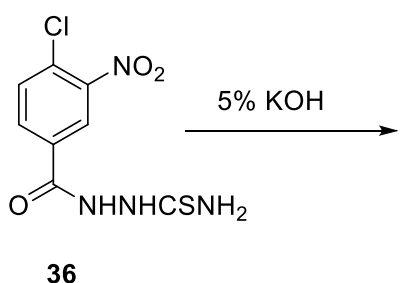

36
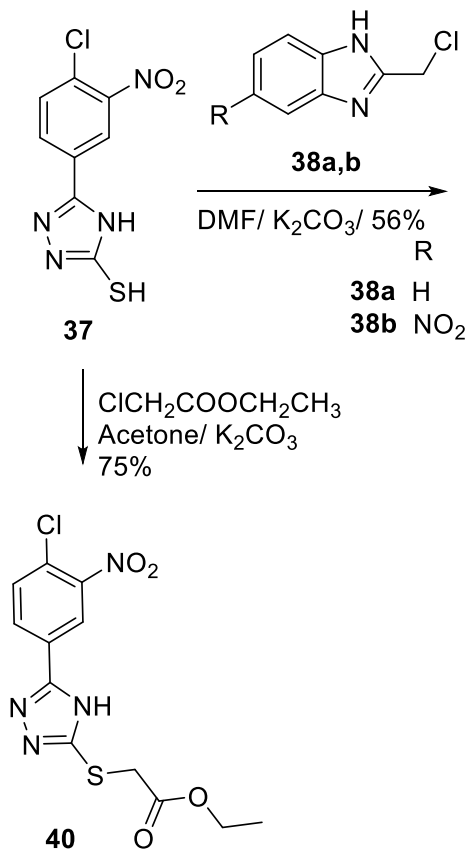

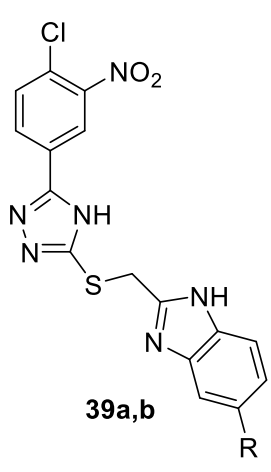

$R$

39a $\mathrm{H}$ $39 \mathrm{~b} \mathrm{NO}_{2}$

\section{Scheme 11}


Scheme 12 outlines the synthesis of triazole derivatives $\mathbf{4 4 a - c . ~ T h e ~ e s t e r ~} \mathbf{4 2}$ which was prepared by reaction of 4-chloro-3-nitrobenzoic acid (41) with methanol/ concentrated $\mathrm{H}_{2} \mathrm{SO}_{4}$ was further reacted with the triazole derivatives $43 a-c$ in presence of $\mathrm{K}_{2} \mathrm{CO}_{3}$ in DMF to obtain the triazoles $44 a-c$.

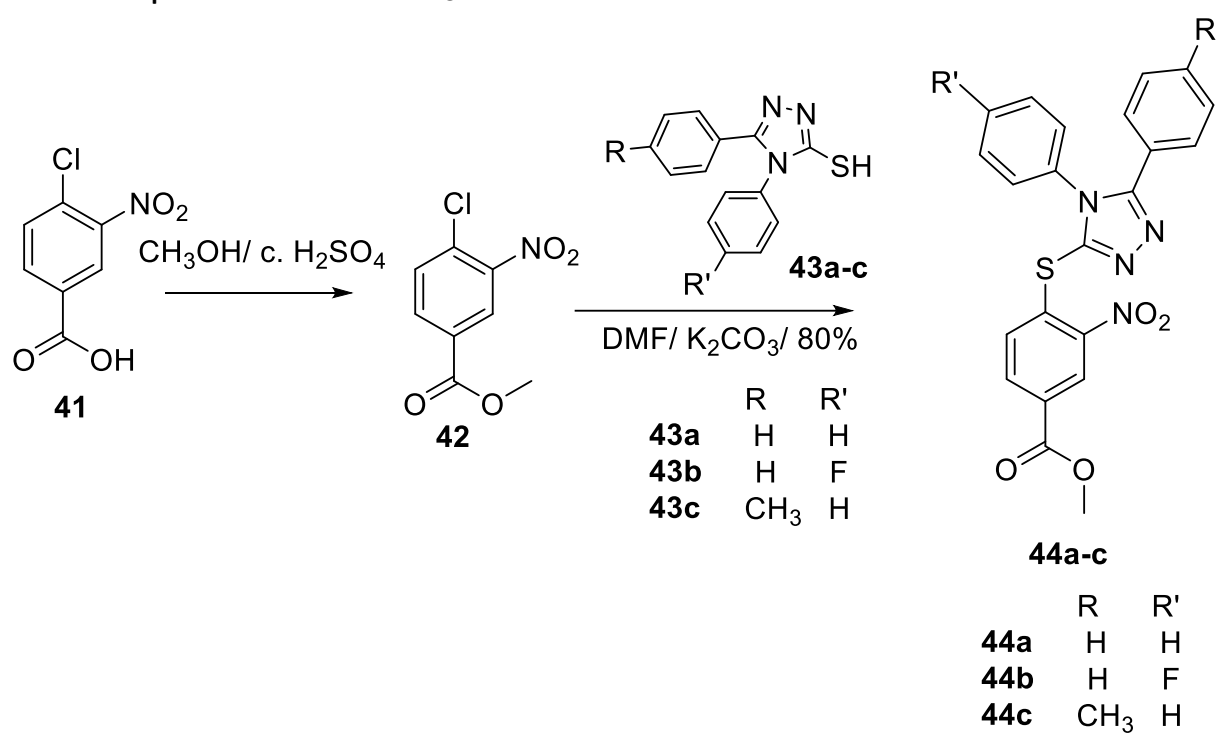

\section{Scheme 12}

\section{Thiadiazoles}

The thiadiazole derivatives synthesized by our group were tested for their activity against avian influenza and showed excellent activity. ${ }^{47}$
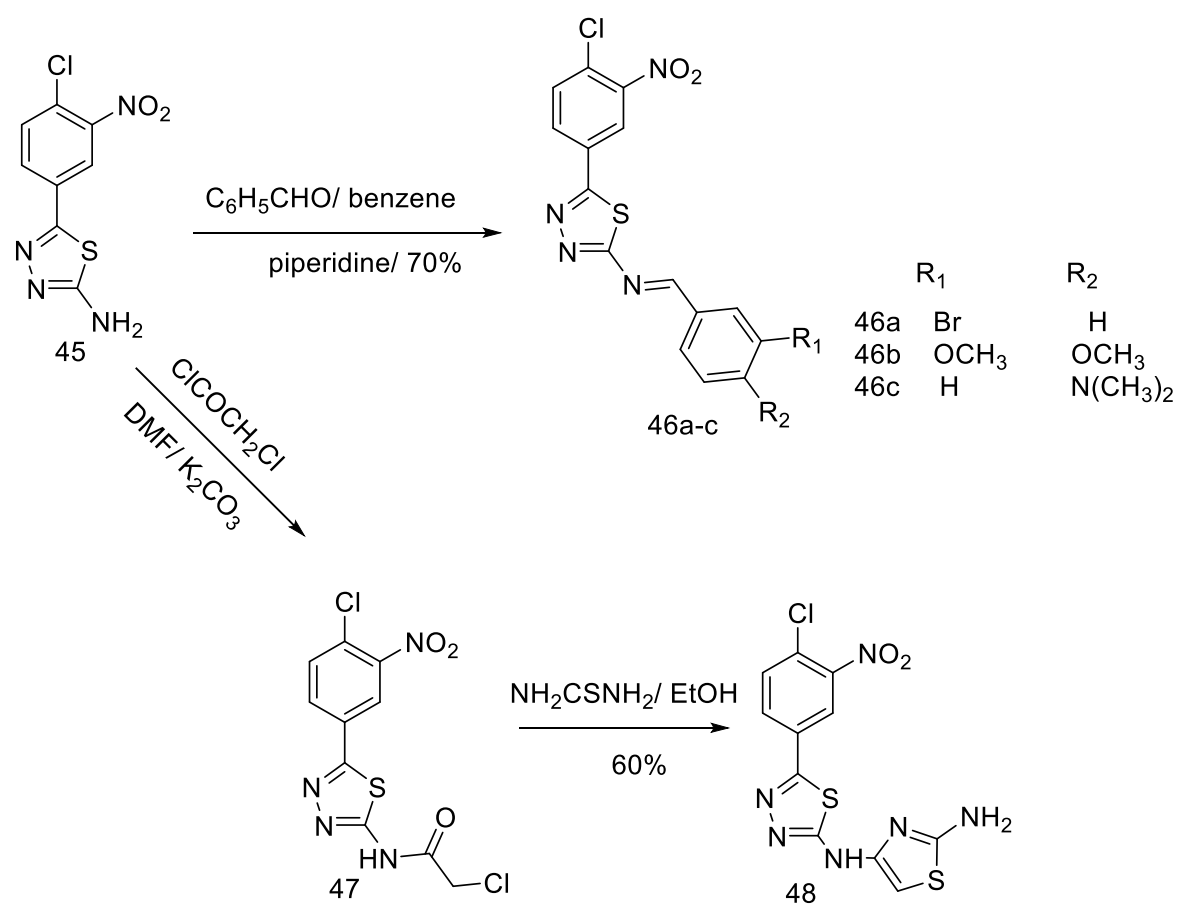

Scheme 13 


\section{Pyrazoles}

While in the medicinal chemistry field, only limited reports have appeared involving the study of the antiinfluenza activity of the pyrazole-containing compounds. Shin et al. searched for novel anti-influenza inhibitors using a cell-based neutralization assay. After screening 20,800 randomly selected compounds, they found that BPR1P0034 (figure 2) has sub-micromolar antiviral activity. Lead optimization and a structure-activity analysis were used to improve potency. Time-of-addition assay was performed to target an event in the virus life cycle. BPR1P0034 is the first pyrazole-based anti-influenza compound ever identified and showed potent (sub- $\mu \mathrm{M}$ ) antiviral activity, which offers an opportunity for the development of a new anti-influenza virus agents. ${ }^{51}$

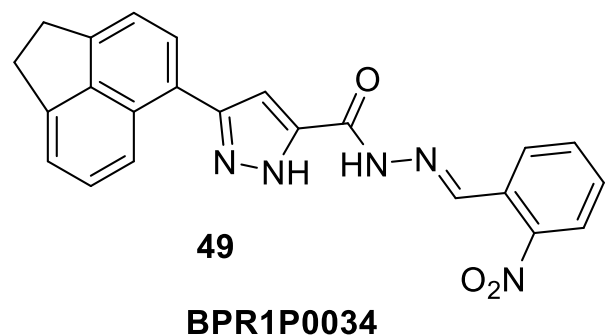

Figure 2. BPR1P0034, the pyrazole derivative with anti-influenza activity.

\section{Imidazoles}

In 2015, Wang et al. designed and synthesized a series of new substituted phenyl-coupled heterocyclic ethyl amide derivatives as anti-influenza agents. The activities of these compounds were investigated and compared to those of the commercial antiviral drugs (Arbidol and Ribavirin) against influenza. Among these new compounds exhibiting moderate levels of antiviral activity against influenza A, compounds 52a-c are the most effective ones, and are as efficacious as the positive control Ribavirin and even much more effective than Ingavirin and Arbidol, indicating that they can be lead candidates for further exploration. These results are also consistent with the docking study results in terms of the design of compounds targeting influenza A via viral nucleoprotein.

The synthesis of the target compounds is shown in scheme 14. To the heterocyclic ethylamine hydrochloride, a solution of $\mathrm{NaOH}$ was added in ethanol and stirred at room temperature for $1 \mathrm{~h}$. After filtration, the filtrate was evaporated to dryness and redissolved in THF. 2-Chloro-4-nitrobenzoic acid and IBCF were stirred in an ice bath for 30 minutes and followed by the addition of the corresponding free amine in THF, and NMM was added, successively, stirred overnight to obtain the target compounds. ${ }^{52}$ 


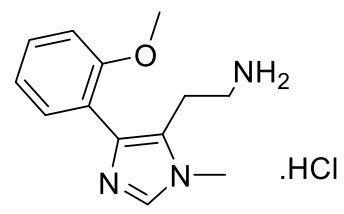

50 a) $\mathrm{NaOH} / \mathrm{EtOH}, 0$ C- r.t./ $1 \mathrm{~h}$

b)<smiles>O=C(O)c1ccc([N+](=O)[O-])cc1Cl</smiles><smiles>[R]CCNC(=O)c1ccc([N+](=O)[O-])cc1Cl</smiles>

IBCF/ NMM/ THF, 0 C- r.t./ overnight/ $84 \%$
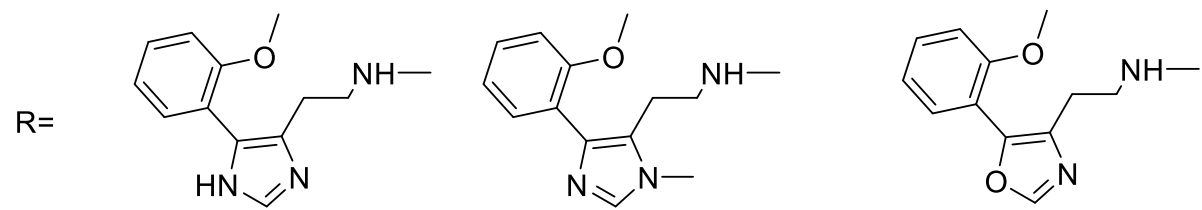

\section{Scheme 14}

\section{Tetrazoles}

Hit compounds with anti-influenza virus activity were selected by in silico screening and tested to determine their anti-influenza virus activities via cell-based screening. Potent compounds with anti-influenza virus activities (MIC value $<20 \mu \mathrm{M}$ ) containing tetrazole moiety are shown in figure $3 .{ }^{53}$<smiles>Cc1cccc2cc(C(c3nnnn3C(C)(C)C)N(CCc3ccccc3)Cc3ccccc3)c(=O)[nH]c12</smiles>

53

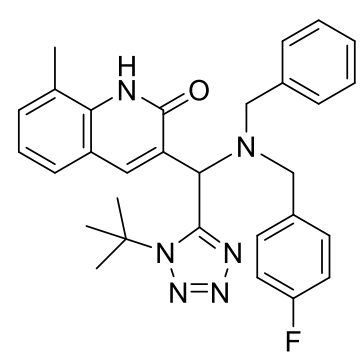

56<smiles>Cc1ccc2cc(C(c3nnnn3C(C)(C)C)N(Cc3ccc(Cl)cc3)Cc3ccco3)c(=O)[nH]c2c1</smiles>

54<smiles>CCc1ccc2[nH]c(=O)c(C(c3nnnn3Cc3ccco3)N(Cc3cccnc3)Cc3ccccc3Cl)cc2c1</smiles>

57<smiles>Cc1cc(C)c2[nH]c(=O)c(C(c3nnnn3C(C)(C)C)N(Cc3ccccc3)Cc3ccccc3)cc2c1</smiles>

55

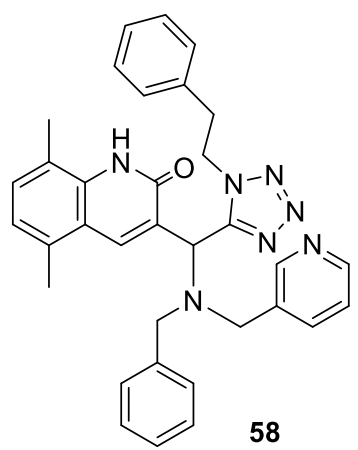

Figure 3. Tetrazole containing compounds with potent anti-influenza activity. 


\section{Conclusions}

This review covers the literature data, best to our knowledge, that study the chemistry of synthesis of compounds, medications under study and drugs that contain five membered heterocycles that show antiinfluenza activity. Furthermore, we made a brief review of the anti-influenza activity of these compounds. The authors believe that this review will be a useful resource for researchers working on developing of antiinfluenza agents.

\section{References}

1. Cox, N. J.; Subbarao, K. The Lancet 1999, 354, 1277. https://doi.org/10.1016/S0140-6736(99)01241-6

2. van Elden, L. J.; van Essen, G. A.; Boucher, C. A.; van Loon, A. M.; Nijhuis, M.; Schipper, P.; Verheij, T. J.; Hoepelman, I. M. Br. J. Gen. Pract. 2001, 51, 630.

3. Cao, B.; Li, X. W.; Mao, Y.; Wang, J.; Lu, H. Z.; Chen, Y. S.; Liang, Z. A.; Liang, L.; Zhang, S. J.; Zhang, B.; Gu, L.; Lu, L. H.; Wang, D. Y.; Wang, C.; National Influenza, A. P. C. I. G. o. C. N. Engl. J. Med. 2009, 361, 2507.

https://doi.org/10.1056/NEJMoa0906612

4. Jain, S.; Kamimoto, L.; Bramley, A. M.; Schmitz, A. M.; Benoit, S. R.; Louie, J.; Sugerman, D. E.; Druckenmiller, J. K.; Ritger, K. A.; Chugh, R.; Jasuja, S.; Deutscher, M.; Chen, S.; Walker, J. D.; Duchin, J. S.; Lett, S.; Soliva, S.; Wells, E. V.; Swerdlow, D.; Uyeki, T. M.; Fiore, A. E.; Olsen, S. J.; Fry, A. M.; Bridges, C. B.; Finelli, L.; Pandemic Influenza, A. V. H. I. T. N. Engl. J. Med. 2009, 361, 1935.

https://doi.org/10.1056/NEJMoa0906695

5. World Health Organization Fact Sheet November 2018, http://apps.who.int/iris/bitstream/handle/10665/272596/9789241565585-eng.pdf

6. Li, T. C.; Chan, M. C.; Lee, N. Viruses 2015, 7, 4929. https://doi.org/10.3390/v7092850

7. Kempegowda; Kumar, S.; Prakash, D.; Mani, T. Der Pharma Chem. 2011, 3, 330.

8. Colanceska-Ragenovic, K.; Dimova, V.; Kakurinov, V.; Molnar, D. G.; Buzarovska, A. Molecules 2001, 6, 815.

https://doi.org/10.3390/61000815

9. Maarouf, A. R.; Farahat, A. A.; Selim, K. B.; Eisa, H. M. Med. Chem. Res. 2011, 21, 703. https://doi.org/10.1007/s00044-011-9574-8

10. Eisa, H.; Barghash, A.-e. M.; Badr, S. M.; Farahat, A. A. Indian J. Chem. Sect. B Org. Med. Chem. 2010, 49, 1515.

11. Morsy, S. A.; Farahat, A. A.; Nasr, M. N. A.; Tantawy, A. S. Saudi Pharm. J. 2017, 25, 873. https://doi.org/10.1016/i.jsps.2017.02.003

12. Branowska, D.; Farahat, A. A.; Kumar, A.; Wenzler, T.; Brun, R.; Liu, Y.; Wilson, W. D.; Boykin, D. W. Bioorg. Med. Chem. 2010, 18, 3551.

https://doi.org/10.1016/i.bmc.2010.03.058

13. Almasirad, A.; Tabatabai, S. A.; Faizi, M.; Kebriaeezadeh, A.; Mehrabi, N.; Dalvandi, A.; Shafiee, A. Bioorg. Med. Chem. Lett. 2004, 14, 6057. 
14. Ramandeep, K.; Ashish Ranjan, D.; Bhupinder, K.; Vinod, K. Anti-Cancer Agents Med. Chem. 2016, 16, 465.

https://doi.org/10.2174/1871520615666150819121106

15. Kattimani, P. P.; Kamble, R. R.; Kariduraganavar, M. Y.; Dorababu, A.; Hunnur, R. K. Eur. J. Med. Chem. 2013, 62, 232.

https://doi.org/10.1016/i.ejmech.2013.01.004

16. Almasirad, A.; Mousavi, Z.; Tajik, M.; Assarzadeh, M. J.; Shafiee, A. Daru J. Pharm. Sci. 2014, $22,22$. https://doi.org/10.1186/2008-2231-22-22

17. Barbuceanu, S.-F.; Ilies, D. C.; Saramet, G.; Uivarosi, V.; Draghici, C.; Radulescu, V. Int. J. Mol. Sci. 2014, 15, 10908.

https://doi.org/10.3390/ijms150610908

18. Abdel-Fattah, H. A.; El-Etrawy, A. S.; Gabr, N. R. M. Int. J. Pharm. Chem. 2014, 4, 112.

19. Li, Y.-H.; Zhang, B.; Yang, H.-K.; Li, Q.; Diao, P.-C.; You, W.-W.; Zhao, P.-L. Eur. J. Med. Chem. 2017, 125, 1098.

https://doi.org/10.1016/i.ejmech.2016.10.051

20. Sonawane, A. D.; Rode, N. D.; Nawale, L.; Joshi, R. R.; Joshi, R. A.; Likhite, A. P.; Sarkar, D. Chem. Biol. Drug Des. 2017, 90, 200.

21. Shivarama Holla, B.; Narayana Poojary, K.; Sooryanarayana Rao, B.; Shivananda, M. K. Eur. J. Med. Chem. 2002, 37, 511.

https://doi.org/10.1016/S0223-5234(02)01358-2

22. Srestha, N.; Banerjee, J.; Srivastava, S. IOSR J. Pharm. 2014, 04, 28. https://doi.org/10.9790/3013-0401201028041

23. Ateş, O. K., A.; Saniş, G. O.; Ekinci, A. C.; Vidin, A. Arzneimittel-forschung 1997, 47, 1134.

24. Padmavathi, V.; Mahesh, K.; Nagendra Mohan, A. V.; Padmaja, A. Chem. Pharm. Bull. 2009, 57, 561. https://doi.org/10.1248/cpb.57.561

25. Fan, Z.; Yang, Z.; Zhang, H.; Mi, N.; Wang, H.; Cai, F.; Zuo, X.; Zheng, Q.; Song, H. J. Agric. Food Chem. 2010, 58, 2630.

26. Zuo, X.; Mi, N.; Fan, Z.; Zheng, Q.; Zhang, H.; Wang, H.; Yang, Z. J. Agric. Food Chem. 2010, $58,2755$. https://doi.org/10.1021/jf902863z

27. Tripathy, R.; Ghose, A.; Singh, J.; Bacon, E. R.; Angeles, T. S.; Yang, S. X.; Albom, M. S.; Aimone, L. D.; Herman, J. L.; Mallamo, J. P. Bioorg. Med. Chem. Lett. 2007, 17, 1793.

https://doi.org/10.1016/i.bmcl.2006.12.054

28. Fadda, A. A.; Abdel-Rahman, A. A. H.; El-Sayed, W. A.; Zidan, T. A.; Badria, F. A. Chem Heterocycl Compd 2011, 47, 856.

https://doi.org/10.1007/s10593-011-0847-4

29. Naik, R.; Patil, S. C.; Satyanarayan, S. B. Indo Am. J. Pharm. Res. 2014, 4, 3763.

30. De Clercq, E.; Field, H. J. Br. J. Pharmacol .2006, 147, 1. https://doi.org/10.1038/sj.bjp.0706446

31. Johns, B. A.; Weatherhead, J. G.; Allen, S. H.; Thompson, J. B.; Garvey, E. P.; Foster, S. A.; Jeffrey, J. L.; Miller, W. H. Bioorg. Med. Chem. Lett. 2009, 19, 1802.

https://doi.org/10.1016/i.bmcl.2009.01.090

32. Dong, W.-L.; Liu, Z.-X.; Liu, X.-H.; Li, Z.-M.; Zhao, W.-G. Eur. J. Med. Chem. 2010, 45, 1919. https://doi.org/10.1016/i.ejmech.2010.01.032

33. De Clercq, E. Biochimica et Biophysica Acta (BBA) - Molecular Basis of Disease 2002, 1587, 258. 
https://doi.org/10.1016/S0925-4439(02)00089-3

34. El-Emam, A. A.; Al-Deeb, O. A.; Al-Omar, M.; Lehmann, J. Bioorg. Med. Chem. 2004, 12, 5107.

35. Farghaly, A.-R.; El-Kashef, H. Arkivoc 2006, 2006, 76.

https://doi.org/10.3998/ark.5550190.0007.b07

36. Tawfik, S. S. L., Mengyao; Farahat, Abdelbasset A. Arkivoc 2020, 180.

https://doi.org/10.24820/ark.5550190.p011.308

37. Kao, R. Y.; Yang, D.; Lau, L.-S.; Tsui, W. H. W.; Hu, L.; Dai, J.; Chan, M.-P.; Chan, C.-M.; Wang, P.; Zheng, B.-J.; Sun, J.; Huang, J.-D.; Madar, J.; Chen, G.; Chen, H.; Guan, Y.; Yuen, K.-Y. Nat. Biotechnol. 2010, 28,600 .

https://doi.org/10.1038/nbt.1638

38. Stein, D. S.; Creticos, C. M.; Jackson, G. G.; Bernstein, J. M.; Hayden, F. G.; Schiff, G. M.; Bernstein, D. I. Antimicrob. Agents Chemother. 1987, 31, 1285.

https://doi.org/10.1128/AAC.31.8.1285

39. Sidwell, R. W.; Bailey, K. W.; Wong, M. H.; Barnard, D. L.; Smee, D. F. Antivir. Res. 2005, 68, 10. https://doi.org/10.1016/i.antiviral.2005.06.003

40. Perwitasari, O.; Johnson, S.; Yan, X.; Howerth, E.; Shacham, S.; Landesman, Y.; Baloglu, E.; McCauley, D.; Tamir, S.; Tompkins, S. M.; Tripp Ralph, A.; Williams, B. J. Virol. 2014, 88, 10228.

https://doi.org/10.1128/JVI.01774-14

41. Rossignol, J.-F. Antivir. Res. 2014, 110, 94.

https://doi.org/10.1016/j.antiviral.2014.07.014

42. Zhao, L.; Yan, Y.; Dai, Q.; Li, X.; Xu, K.; Zou, G.; Yang, K.; Li, W.; Guo, X.; Yang, J.; Li, Y.; Xia, Q.; Cao, R.; Zhong, W. Antimicrob. Agents Chemother 2020, 64, e00222.

https://doi.org/10.1128/AAC.00222-20

43. Yarovaya, O. I.; Sokolova, A. S.; Mainagashev, I. Y.; Volobueva, A. S.; Lantseva, K.; Borisevich, S. S.; Shtro, A. A.; Zarubaev, V. V.; Salakhutdinov, N. F. Bioorg. Med. Chem. Lett. 2019, 29, 126745. https://doi.org/10.1016/j.bmcl.2019.126745

44. Wang, W.-L.; Yao, D.-Y.; Gu, M.; Fan, M.-Z.; Li, J.-Y.; Xing, Y.-C.; Nan, F.-J. Bioorg. Med. Chem. Lett. 2005, 15, 5284.

https://doi.org/10.1016/j.bmcl.2005.08.046

45. Tolan, H. E. M.; El-Sayed, W. A.; Tawfek, N.; Abdel-Megeid, F. M. E.; Kutkat, O. M. Nucleosides Nucleotides Nucleic Acids 2020, 39, 649.

https://doi.org/10.1080/15257770.2019.1674331

46. Seliverstova, D. V.; Suslonov, V. V.; Zarubaev, V. V.; Trifonov, R. E. Russian J. Org. Chem. 2018, 54, 633.

47. Tawfik, S. S.; Farahat, A. A.; A.-A El-Sayed, M.; Tantawy, A. S.; Bagato, O.; Ali, M. A. Lett. Drug Des. Discov. 2018, 15, 363.

https://doi.org/10.2174/1570180814666170512122832

48. Flefel, E. M.; Abdel-Mageid, R. E.; Tantawy, W. A.; Ali, M. A.; Amr, A. E.-G. E. Acta Pharm. 2013, 62, 593.

49. Su, Y.; Meng, L.; Sun, J.; Li, W.; Shao, L.; Chen, K.; Zhou, D.; Yang, F.; Yu, F. Eur. J. Med. Chem. 2019, $182,111622$.

https://doi.org/10.1016/i.ejmech.2019.111622

50. Cheng, H.; Wan, J.; Lin, M.-I.; Liu, Y.; Lu, X.; Liu, J.; Xu, Y.; Chen, J.; Tu, Z.; Cheng, Y.-S. E.; Ding, K. J. Med. Chem. 2012, 55, 2144. 
https://doi.org/10.1021/jm2013503

51. Shih, S.-R.; Chu, T.-Y.; Reddy, G. R.; Tseng, S.-N.; Chen, H.-L.; Tang, W.-F.; Wu, M.-S.; Yeh, J.-Y.; Chao, Y.-S.; Hsu, J. T. A.; Hsieh, H.-P.; Horng, J.-T. J. Biomed. Sci. 2010, 17, 13. https://doi.org/10.1186/1423-0127-17-13

52. Wang, Y.; Lei, F.; Li, X.; He, Y.; Li, J.; Qiu, R.; Wu, X.; Hai, L.; Wu, Y. Chem. Res. Chin. U. 2015, $31,942$. https://doi.org/10.1007/s40242-015-5197-9

53. Watanabe, K.; Ishikawa, T.; Otaki, H.; Mizuta, S.; Hamada, T.; Nakagaki, T.; Ishibashi, D.; Urata, S.; Yasuda, J.; Tanaka, Y.; Nishida, N. Sci. Rep. 2017, 7, 9500.

https://doi.org/10.1038/s41598-017-10021-w

\section{Authors' Biographies}

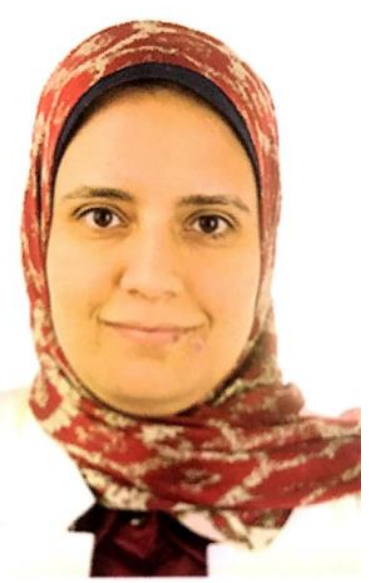

Dr. Samar Tawfik received a bachelor's degree in Pharmaceutical Science, Mansoura University, Egypt, 2006, Master's degree in Pharmaceutical Organic Chemistry, Mansoura University, 2012, and Ph.D. in Pharmaceutical Organic Chemistry, Mansoura University, 2017 under Supervision of Prof. Atef Tantawy. Dr. Samir is working now as an assistant professor of Pharmaceutical Organic Chemistry, Mansoura University, Egypt. Dr. Samir is interested in the design and synthesis of new compounds to be investigated as antiviral agents, especially those acting as anti-influenza.

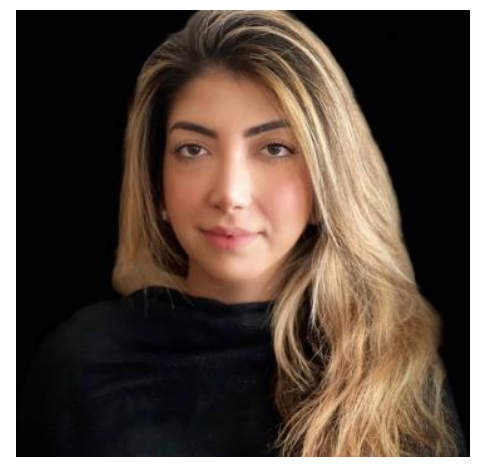

Sadaf Zarechian is a graduate of the University of California, Santa Cruz majoring in Molecular, Cell, and Development Biology B.S. She is currently in her second year of the Master of Pharmaceutical Sciences program at California Northstate University. 


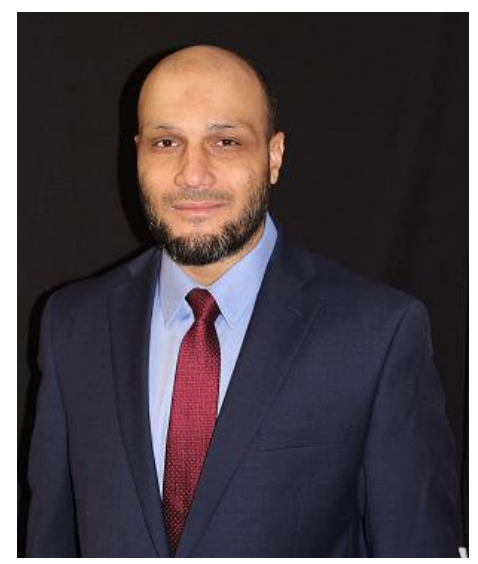

Dr. Abdelbasset Farahat is an Assistant Professor of Pharmaceutical and Medicinal Chemistry in the Department of Pharmaceutical and Biomedical Sciences, Master of Pharmaceutical Sciences at California Northstate University. In 2002, Dr. Farahat received a Bachelor of Pharmacy from Mansoura University Egypt, and then in 2006, he received a Master of Pharmaceutical Sciences from Mansoura University Egypt. In 2010 Dr. Farahat received his Ph.D. in Medicinal Chemistry after doing research at Georgia State University, Atlanta, GA, USA under the supervision of Prof. David W. Boykin. His research focuses on the design and synthesis of dicationic compounds to be used as antimalarial and antitrypanosomal agents. 